\title{
Follow up study of workers manufacturing chrysotile asbestos cement products
}

\author{
M J GARDNER, P D WINTER, B PANNETT, C A POWELL \\ From the Medical Research Council Environmental Epidemiology Unit (University of Southampton), \\ Southampton General Hospital, Southampton SO9 4XY, UK
}

\begin{abstract}
A cohort study has been carried out of 2167 subjects employed between 1941 and 1983 at an asbestos cement factory in England. The production process incorporated the use of chrysotile asbestos fibre only, except for a small amount of amosite during four months in 1976. Measured airborne fibre concentrations available since 1970 from personal samplers showed mean levels below 1 fibre $/ \mathrm{ml}$, although higher levels had probably occurred previously in certain areas of the factory. No excess of lung cancer was observed in the mortality follow up by comparison with either national or local death rates, and analyses of subgroups of the workforce by job, exposure level, duration of employment, duration since entry, or calendar years of employment gave no real suggestion of an asbestos related excess for this cause of death. There was one death from pleural mesothelioma and one with asbestosis mentioned as an associated cause on the death certificate, but neither is thought to be linked to asbestos exposure at this factory. Other suggested asbestos related cancers, such as laryngeal and gastrointestinal, did not show raised risks. Although the durations of exposure were short in this study, the findings are consistent with two other studies of workers exposed to low concentrations of chrysotile fibre in the manufacture of asbestos cement products which reported no excess mortality.
\end{abstract}

The potential ill health effects of exposure to asbestos have been recognised for many years. What is not yet totally apparent, however, is the degree to which the effects vary for different types of asbestos fibre and across different sections of the asbestos using industry. There are, nevertheless, strong indications that the amphiboles, crocidolite (blue asbestos) and amosite (brown asbestos), have been more dangerous for causing mesothelioma in man than chrysotile (white asbestos)-although this is not so clear for lung cancer. ${ }^{12}$ There is also evidence that asbestos related diseases have occurred at higher rates in some industries than in others-for example, the manufacture of insulation products ${ }^{3}$ compared with friction materials. ${ }^{4}$

Imports of crocidolite to the United Kingdom had essentially stopped by the early 1970 s and of amosite by the early 1980s. In an update of reports on asbestos and ill health, Acheson and Gardner drew attention to the fact that the use of chrysotile asbestos in cement

Accepted 3 April 1986 for building products was the main current activity (by tonnage) of the asbestos industry. ${ }^{1}$ As little epidemiological information was available about the health of workers in this industry, they recommended that further research should be carried out. This proposal was supported by Doll and Peto. ${ }^{2}$

The single existing study of asbestos cement workers using almost exclusively chrysotile was from a factory in South Wales, ${ }^{5}$ in which there had been no suggestion to the end of 1977 of an excess of deaths from lung cancer ( 30 observed, 33 expected) nor were any cases of asbestosis reported. The two deaths from pleural mesothelioma which had taken place among the workforce were of men who had been employed in the factory from 1932 to 1935 when crocidolite was being used. No further follow up information on this cohort is currently available (PC Elwood, personal communication).

\section{Methods}

BACKGROUND

At the outset of this study a detailed investigation of 
Table 1 Imports of asbestos in tonnes into the United Kingdom since 1980

\begin{tabular}{llll}
\hline & Raw fibre & & $\begin{array}{l}\text { In chrysotile } \\
\text { asbestos } \\
\text { cement }\end{array}$ \\
\cline { 2 - 4 } Year & Chrysotile & Amosite & $?$ \\
\hline 1980 & 94650 & 700 & $?$ \\
1981 & 67250 & 260 & 6150 \\
1982 & 54000 & 20 & 10200 \\
1983 & 44600 & - & 10300 \\
1984 & 40000 & - & \\
\hline
\end{tabular}

Source: Figures provided by the Asbestos Information Centre Ltd (W Penney, personal communication).

all asbestos cement factories in the country was made, using information submitted by industry to the Advisory Committee on Asbestos ${ }^{6}$ and descriptions provided by the Asbestos Information Centre, (W Penney, personal communication) among other sources. Clearly most asbestos cement factories had used amphiboles in large quantities and were thus unsuitable for inclusion.

Of the three factories identified which had reported using only chrysotile, two proved to be unsatisfactory-one because records of workers before the early 1960s were not available and the other because it only came into operation in 1966 with a consequent limitation of current potential follow up to less than 20 years. The third factory (TAC Construction Materials Ltd, Tamworth) has been, therefore, the only one studied.

Recent figures on asbestos imports into the United Kingdom show a continued decline in amounts of raw fibre (table 1). Of the estimated 40000 tonnes of chrysotile imported in 1984 , about $35 \%$ was used in the manufacture of asbestos cement products, $20 \%$ in friction materials, $13 \%$ in jointings and packings, $7 \%$ in textiles, and the remaining $25 \%$ in various other products. Imports of chrysotile asbestos cement in recent years have meant that the overall annual fall has not been as pronounced as that suggested by the figures for raw fibre.

\section{FACTORY AND PRODUCTION PROCESS}

The site was occupied for some 80 years by a paper mill until the early 1930s when the production of hand moulded corrugated asbestos cement sheets began. The present company took over in early 1941 and during the second world war manufactured flat and curved roofing sheets for aircraft hangers. After the war the main products were for the prefabricated housing programme. Since 1951 the major output has been corrugated roofing sheets and associated fittings and mouldings, with some pressure piping during 1951-4. During this whole period only chrysotile asbestos has been used except for a short experimental programme of four months (August to November,
1976) when a small quantity-about 145 tonnes-of amosite was used. Annual output of finished products has ranged from about 18000 tonnes during the second world war, through a peak of over 65000 tonnes in the $1960 \mathrm{~s}$, to some 50000 tonnes in the early 1980 s - of which about $10 \%$ by weight was chrysotile.

The basic process consists of mixing asbestos fibre, water, and cement to a suitable consistency and feeding this on to a Hatschek paper machine where a web is picked up by a moving felt and transferred on to a large roller. When a suitable thickness has built up, required lengths are cut. The wet sheet is then carried along a conveyor belt and trimmed before being passed on to corrugated steel templates and stored to harden at room temperature. After this approximately $10 \%$ of the hardened sheets are sawn to produce shorter or special lengths. Mouldings and other fittings are usually shaped and trimmed by hand using pieces taken from the same wet mixture.

The type of chrysotile currently used in the factory is "Havelock" fibre from Zwaziland, which is regarded as a pure and clean form of chrysotile. In the past fibre was mainly imported from Rhodesia until the Unilateral Declaration of Independence and sanctions in 1965, and then from Canada until the early 1980 s. Originally the chrysotile fibre was delivered in unlined hessian sacks and milled to remove any lumps. After milling the fibre was rebagged into permeable sacks from which it was fed by hand into the slurry forming vessel (the 'beater'). By 1950 the sacks had plastic liners and from the 1960s the asbestos was being imported in plastic bags. Up until 1975 the bags containing the raw asbestos were opened and tipped into the mixer by hand, but since then this operation has been automated and enclosed.

Exposure to asbestos is potentially highest in the initial fibre handling and finishing areas, with lower levels during the wet stages of the process. During the second world war some dust extraction was provided at the beater, and in 1950 water was introduced to the milling procedure to help dust control. Exhaust ventilation was also improved in 1975, particularly in the sawing and cutting areas, but the "uncured" production area has probably seen the least change over the years in atmospheric fibre levels.

\section{CLASSIFICATION OF THE COHORT, JOBS, AND EXPOSURE}

The company agreed to collaborate in this study during 1983 and made their records available to us. Information on each member of the workforce from 1941 to 1983 was abstracted from the personnel records, and suitable checks on the accuracy of this clerical process were carried out. Basic individual identification details were obtained, together with dates of starting and leaving employment and descrip- 
Table 2 Asbestos fibre levels in different areas of the factory between 1968 and 1982

\begin{tabular}{|c|c|c|c|c|}
\hline $\begin{array}{l}\text { Area of } \\
\text { factory }\end{array}$ & $\begin{array}{l}\text { Period } \\
\text { (years) }\end{array}$ & $\begin{array}{l}\text { Personal or } \\
\text { static samples }\end{array}$ & $\begin{array}{l}\text { No of } \\
\text { readings }\end{array}$ & $\begin{array}{l}\text { Mean level } \\
\text { (fibres } / \mathrm{ml} \text { ) }\end{array}$ \\
\hline \multirow[t]{7}{*}{ Fibre treatment } & $1968-70$ & $\begin{array}{l}P \\
S\end{array}$ & 1 & 0.5 \\
\hline & $1971-74$ & $\vec{P}$ & $\begin{array}{l}20 \\
19\end{array}$ & $\begin{array}{l}2.6 \\
0.5\end{array}$ \\
\hline & & $\mathbf{S}$ & 2 & 0.5 \\
\hline & $1975-78$ & $\mathbf{P}$ & 53 & 0.9 \\
\hline & & $\mathbf{S}$ & 28 & $0 \cdot 2$ \\
\hline & $1979-82$ & $\ddot{P}$ & 38 & 0.8 \\
\hline & & $\mathbf{S}$ & 174 & 0.3 \\
\hline \multirow[t]{3}{*}{ Beater floor } & $1968-69$ & $\mathbf{S}$ & 18 & $6 \cdot 1$ \\
\hline & $1970-74$ & P & 24 & 0.4 \\
\hline & $1975-82$ & $\mathbf{P}$ & 89 & $0 \cdot 2$ \\
\hline \multirow{2}{*}{ Moulded goods } & $1968-69$ & $\mathbf{S}$ & 10 & $3 \cdot 2$ \\
\hline & $1970-82$ & $\mathbf{P}$ & 275 & 0.2 \\
\hline \multirow{3}{*}{ Dry cutting } & $1968-70$ & $\mathbf{S}$ & 18 & 9.0 \\
\hline & $1971-82$ & $\mathbf{P}$ & 136 & 0.8 \\
\hline & $1972-82$ & $\mathbf{S}$ & 10 & 0.2 \\
\hline \multirow{4}{*}{ Hard waste grinding } & $1968-69$ & $\overrightarrow{\mathbf{S}}$ & 10 & 4.5 \\
\hline & $1970-78$ & $\overrightarrow{\mathbf{P}}$ & 44 & 0.7 \\
\hline & 1972 & $\mathbf{S}$ & 4 & 0.3 \\
\hline & $1979-82$ & $\overrightarrow{\mathbf{P}}$ & 12 & 0.3 \\
\hline Miscellaneous & $1973-82$ & $\mathbf{P}$ & 112 & 0.2 \\
\hline
\end{tabular}

tions of all jobs undertaken at the factory.

The job titles as taken from the personnel records have been grouped according to the type of work undertaken and location in the factory. This grouping is aimed at differentiating jobs with exposure to dry asbestos fibre from those in the wet and postcuring stages of the process. The classification was carried out in conjunction with longstanding employees at the factory, and was completed in advance of obtaining the mortality information.

Over 1000 measurements of atmospheric fibre concentrations were made during the period $1968-82$ by the company and have been used to assign codes to job titles to reflect levels of probable exposure. The available mean fibre concentrations are summarised in table 2 . Since 1970 fibre levels have generally been low with mean levels under $1 \mathrm{f} / \mathrm{ml}$ throughout the factory. Only a few exposures over $2 \mathrm{f} / \mathrm{ml}$ have been recorded, and most measured concentrations have been under $0.5 \mathrm{f} / \mathrm{ml}$. Over $70 \%$ of the readings are based on the use of personal samplers. For the period before 1968 it would be reasonable to assume that levels were higher because of less extensive exhaust ventilation and more direct handling of raw asbestos.

\section{THE FOLLOW UP}

Each person identified in the factory records was traced where possible at the National Health Service Central Register (NHSCR) in Southport, and we were provided with information on their current vital status and copies of death certificates where appropriate. On a continuing basis we receive quarterly returns notifying any changes in vital status and further death certificates. Individuals whose records could not be traced at the NHSCR were searched for at the
Department of Health and Social Security (DHSS) office in Newcastle. The availability of National Insurance numbers at the factory for about half of these individuals aided this process.

The mortality analysis reported in this paper is from 1 April 1941 to 31 December 1984, and the underlying cause for each death has been taken from the death certificate. The numbers of observed deaths have been compared with those expected on the basis of the rates for relevant calendar year, cause, sex, and age specific groups for England and Wales. The expected numbers were calculated by the person years method using a computer program (PYCL) adapted from that of Hill. ${ }^{7}$ Local correction factors have been applied to the national expected numbers using available standardised mortality ratios (SMRs) by cause during 1968-78 for the area, Tamworth Municipal Borough (MB), containing the factory. ${ }^{89}$ Confidence intervals have been calculated by the usual methods based on the Poisson distribution.

\section{Results}

Table 3 shows the number of individuals for whom records were abstracted by sex and quality of the information for the purposes of follow up in the NHSCR and for analysis. Some $70 \%$ of the individuals are men compared with $30 \%$ women. Of the overall 2173 individuals for whom records were identified, six $(0 \cdot 3 \%)$ had to be excluded due to lack of suitable identification particulars.

The annual intake of workers fluctuated somewhat. It was higher in 1941, when the factory was first established, and in the early 1950s, when there was an expansion in roofing products and pressure pipes were 
Table 3 Number of individuals for whom records were abstracted by quality of information and sex

$\left.\left.\begin{array}{llcc}\hline \begin{array}{l}\text { Quality of } \\ \text { information }\end{array} & \text { Sex } & \begin{array}{l}\text { No of } \\ \text { individuals }\end{array} & \text { Percentage } \\ \hline \text { Usable } & \text { Men } & 1510 & 69 \cdot 5 \\ & \text { Women } & 657 & 30 \cdot 2 \\ \text { Not usable* } & \text { Men } & 4 \\ \text { Wotal } & \text { Women } & 2\end{array}\right\} \begin{array}{c}0.2 \\ 0.1\end{array}\right\} 0 \cdot 3$

"Five had missing "date of birth" and two had missing "date of starting employment."

first made, than in other years. Otherwise the annual number of new employees was about 30 , although a little higher in the 1970s. The turnover of the workforce was considerable, with $52 \%$ leaving within one year and $82 \%$ within five years of starting employment. About 30 of the workers were employed by the existing factory in 1941.

Table 4 shows the vital status of the 2167 members of the study cohort by sex as at 31 December 1984 . Overall $486(22 \%)$ had died. It was not possible to follow up $77(3.6 \%)$ of the cohort to the end of 1984 due to $38(1.8 \%)$ having emigrated and $39(1.8 \%)$ being untraced at NHSCR or DHSS.

The numbers of deaths to the end of 1984 by sex for the main causes and a comparison with those expected on national rates are given in table 5 . In addition, the SMRs for Tamworth MB for a relevant period are shown for comparison with mortality rates among the local community. ${ }^{11}$ Of the total 486 deaths, $314(65 \%)$ persons were residents of Tamworth MB at the time of their death and a further $117(24 \%)$ deaths occurred in neighbouring areas. In addition, among the 306 individuals for whom we have information from their death certificates on place of birth, 145 $(47 \%)$ were born in Tamworth MB. When examined by calendar year $194(40 \%)$ of the deaths took place during 1968-78, $157(32 \%)$ in 1967 or earlier, and the remaining $135(28 \%)$ between 1979 and the end of 1984.

The overall death rate in each sex is lower than national levels, with $\mathrm{O} / \mathrm{E}$ ratios of 0.94 and 0.92 in men and women respectively. They are also lower than the local area mortality figures, where the SMRs are 109 for men and 106 for women relative to 100 for England and Wales. There is evidence of a slight increase in mortality rates with increasing time since first entry to employment: $O=189, E=219.8$, $\mathrm{O} / \mathrm{E}=0.86$ in the initial 20 years compared with $\mathrm{O}=297, \mathrm{E}=299 \cdot 1, \mathrm{O} / \mathrm{E}=0.99$ in the following years for both sexes combined.

For deaths from cancer the rate is similar to those nationally and locally in men but lower in women. For lung cancer there is a small deficit of observed to expected deaths in men, and in women a slight excess but the numbers are small. No single cancer site shows any suggestion of a statistically significant excess, including those which have been associated with asbestos in other studies, such as oesophagus (ICD No 150; 1 observed, 3.5 expected), stomach (ICD No $151 ; 15$ observed, 13.7 expected), large intestine (ICD No $153 ; 6$ observed, $9 \cdot 2$ expected), rectum (ICD No 154; 5 observed, 6.2 expected), larynx (ICD No 161; 1 observed, $1 \cdot 1$ expected), and ovary (ICD No 183; 3 observed, 2.7 expected). Except for stomach cancer, however, the numbers are small.

There has been one death from mesothelioma (pleural) in the study cohort during the follow up period. It took place within seven years of the man's first date of employment with the company, for whom he worked for under four years. A further death, for which the underlying cause was reported as cancer of the lung, mentioned asbestosis as an associated condition. This death occurred some 33 years after the man had started the first of three brief spells of employment (eight months, four months, and one month) with the company.

Among the other causes of death, there are no indications of any adverse mortality levels. For circulatory diseases in men there is a low $\mathrm{O} / \mathrm{E}$ ratio $(0 \cdot 87)$ compared with national expectation, and this becomes lower $(0.74)$ when the SMR for Tamworth $\mathrm{MB}$ is used as a basis. For non-malignant respiratory diseases in men there is a statistically insignificant increase compared with national rates, but the excess is smaller when contrasted to the local level. In women the only cause of death with large numbers is circulatory disease, which has a similar rate among members of the workforce to the locality.

Table 6 gives details of lung cancer mortality in both sexes in relation to type of job and estimated level of potential exposure to asbestos. As may be seen the observed and expected numbers were similar for workers in the vicinity of raw fibre or handling finished products-for example, sawing, trimming, grinding, or cutting - and this was also true for other workers including those in the "wet" part of the process as well as those concerned with storage, despatch, maintenance, and office work. There is a small sug-

Table 4 Vital status at the end of 1984 by sex for individuals in the study cohort

\begin{tabular}{lrrrrr}
\hline $\begin{array}{l}\text { Status on } \\
31 \text { December } \\
1984\end{array}$ & \multicolumn{2}{l}{ Men } & & & \multicolumn{2}{c}{ Women } \\
\cline { 2 - 3 } \cline { 5 - 6 } & No & $\%$ & & No & $\%$ \\
\hline Alive & 1073 & $71 \cdot 1$ & & 531 & $80 \cdot 8$ \\
Dead & 384 & $25 \cdot 4$ & & 102 & $15 \cdot 5$ \\
Emigrated & 31 & $2 \cdot 1$ & 7 & $1 \cdot 1$ \\
Untraced & 22 & $1 \cdot 5$ & & 17 & $2 \cdot 6$ \\
Total & 1510 & 100 & 657 & 100 \\
\hline
\end{tabular}


Table 5 Mortality by sex and cause of death among the workforce to the end of 1984

\begin{tabular}{|c|c|c|c|c|c|c|}
\hline \multirow[b]{2}{*}{ Cause of death } & \multirow[b]{2}{*}{$I C D N o^{*}$} & \multicolumn{2}{|c|}{ No of deaths $\dagger$} & \multirow[b]{2}{*}{$O / E$} & \multirow{2}{*}{$\begin{array}{l}95 \% \text { Confidence } \\
\text { interval for } O / E\end{array}$} & \multirow{2}{*}{$\begin{array}{l}\text { Local area } \\
\text { SMR }\end{array}$} \\
\hline & & $O$ & $E$ & & & \\
\hline Men & & & & & & \\
\hline $\begin{array}{l}\text { All malignant neoplasms } \\
\text { Cancer of: }\end{array}$ & $140-209$ & 95 & 97 & 0.98 & 0.79 to 1.19 & 96 \\
\hline $\begin{array}{l}\text { Lung } \\
\text { Other sites }\end{array}$ & $162-163$ & $\begin{array}{l}35 \\
60\end{array}$ & $\begin{array}{l}38 \\
59\end{array}$ & $\begin{array}{l}0.92 \\
1.02\end{array}$ & $\begin{array}{l}0.64 \text { to } 1.27 \\
0.77 \text { to } 1.31\end{array}$ & $\begin{array}{l}98 \\
95\end{array}$ \\
\hline $\begin{array}{l}\text { All other causes } \\
\text { Circulatory diseases } \\
\text { Respiratory diseases } \\
\text { Accidents, poisoning, and violence } \\
\text { Other causes }\end{array}$ & $\begin{array}{l}- \\
390-459 \\
460-519 \\
800-999 \\
-\end{array}$ & $\begin{array}{r}289 \\
172 \\
66 \\
19 \\
32\end{array}$ & $\begin{array}{r}311 \\
199 \\
56 \\
19 \\
38\end{array}$ & $\begin{array}{l}0.93 \\
0.87 \\
1 \cdot 19 \\
1.02 \\
0.85\end{array}$ & $\begin{array}{l}0.83 \text { to } 1.04 \\
0.74 \text { to } 1.01 \\
0.92 \text { to } 1.51 \\
0.62 \text { to } 1.60 \\
0.58 \text { to } 1.19\end{array}$ & $\begin{array}{r}113 \\
118 \\
110 \\
96 \\
99\end{array}$ \\
\hline All causes & 000-999 & 384 & 408 & 0.94 & 0.85 to 1.04 & 109 \\
\hline $\begin{array}{l}\text { Women } \\
\text { All malignant neoplasms } \\
\text { Cancer of: }\end{array}$ & $140-209$ & 26 & 34 & $0 \cdot 77$ & 0.50 to $1 \cdot 13$ & 95 \\
\hline Lung & $\frac{162-163}{-}$ & $\begin{array}{r}6 \\
20\end{array}$ & 29 & $\begin{array}{l}1.42 \\
0.68\end{array}$ & $\begin{array}{l}0.52 \text { to } 3.10 \\
0.42 \text { to } 1.05\end{array}$ & $\begin{array}{l}73 \\
97\end{array}$ \\
\hline $\begin{array}{l}\text { All other causes } \\
\text { Circulatory diseases } \\
\text { Respiratory diseases } \\
\text { Accidents, poisoning, and violence } \\
\text { Other causes }\end{array}$ & $\begin{array}{l}\overline{390}-459 \\
460-519 \\
800-999 \\
-\end{array}$ & $\begin{array}{r}76 \\
54 \\
8 \\
4 \\
10\end{array}$ & $\begin{array}{l}78 \\
47 \\
11 \\
4 \cdot 6 \\
16\end{array}$ & $\begin{array}{l}0.98 \\
1.16 \\
0.74 \\
0.87 \\
0.64\end{array}$ & $\begin{array}{l}0.77 \text { to } 1.23 \\
0.87 \text { to } 1.51 \\
0.32 \text { to } 1.46 \\
0.24 \text { to } 2.23 \\
0.31 \text { to } 1.18\end{array}$ & $\begin{array}{r}108 \\
119 \\
86 \\
90 \\
100\end{array}$ \\
\hline All causes & 000-999 & 102 & 111 & 0.92 & 0.75 to $1 \cdot 11$ & 106 \\
\hline
\end{tabular}

*International Classification of Diseases, 9 th revision. ${ }^{10}$

†O = Observed deaths; $\mathrm{E}=$ Expected deaths at calendar year, cause, sex, and age specific rates for England and Wales.

†Local area SMRs are based on mortality in Tamworth Municipal Borough during 1968-78. ${ }^{89}$

Table 6 Lung cancer mortality by job with highest exposure category and by highest exposure level experienced

(a) Job category

\begin{tabular}{lccccc}
\hline & & \multicolumn{2}{c}{ Lung cancer deaths } & \multicolumn{2}{c}{$95 \%$ CI for } \\
\cline { 2 - 6 } Job category & No of subjects & $O$ & $E$ & $O / E$ & $0 / E$ \\
\hline Handling raw fibre & 72 & 3 & 2.2 & 1.38 & 0.29 to 4.04 \\
Handling dry products & 396 & 71.03 & 0.42 to 2.13 \\
Other & 1699 & 31 & 33.5 & 0.93 & 0.63 to 1.32 \\
Total & 2167 & 41 & 42.4 & 0.97 & 0.69 to 1.31 \\
\hline
\end{tabular}

(b) Exposure level

\begin{tabular}{|c|c|c|c|c|c|}
\hline \multirow[b]{2}{*}{ Exposure level (fibres/ml) } & \multirow[b]{2}{*}{ No of subjects } & \multicolumn{2}{|c|}{ Lung cancer deaths } & \multirow[b]{2}{*}{$O / E$} & \multirow{2}{*}{$\begin{array}{l}95 \% \text { CI for } \\
O / E\end{array}$} \\
\hline & & $O$ & $E$ & & \\
\hline $\begin{array}{l}\geqslant 5 \\
2-4.9 \\
1-1.9 \\
0.1-0.9 \\
\text { Under } 0.1 \\
\text { Unexposed } \\
\text { Unknown }\end{array}$ & $\begin{array}{r}87 \\
18 \\
33 \\
1278 \\
508 \\
234 \\
9\end{array}$ & $\begin{array}{r}5 \\
0 \\
0 \\
27 \\
6 \\
2 \\
1\end{array}$ & $\begin{array}{r}2.2 \\
0.9 \\
1 \cdot 0 \\
28 \cdot 0 \\
7 \cdot 0 \\
3 \cdot 2 \\
0.2\end{array}$ & $\begin{array}{l}2 \cdot 24 \\
0 \\
0 \\
0.97 \\
0.86 \\
0.63 \\
4.32\end{array}$ & $\begin{array}{l}0.73 \text { to } 5.23 \\
0 \quad \text { to } 4.28 \\
0 \quad \text { to } 3.72 \\
0.64 \text { to } 1.41 \\
0.32 \text { to } 1.88 \\
0.08 \text { to } 2.28 \\
0.11 \text { to } 24.09\end{array}$ \\
\hline Total & 2167 & 41 & $42 \cdot 4$ & 0.97 & 0.69 to 1.31 \\
\hline
\end{tabular}

gestion of a relation with fibre concentration, but the numbers concerned are unsubstantial. Of the five deaths from lung cancer with highest exposures of more than $5 \mathrm{f} / \mathrm{ml}$, two worked for less than one week, two more for about one year, and the other for 4.5 years. In terms of the follow up time since experi- encing these exposures three $(0.8$ expected) of the deaths occurred within 20 years compared with two ( 1.4 expected) after 20 years.

Other aspects of the lung cancer mortality results also do not suggest any particular relation to fibre exposure. Thus overall, 16 (17.6 expected) deaths 
occurred within 20 years of starting employment and 25 ( 24.8 expected) later; 22 ( 21.0 expected) deaths occurred in subjects first employed in the 1940s compared with 19 (21.4 expected) in those starting from the 1950s; 22 (19.5 expected) deaths took place in subjects employed for less than one year contrasted to 19 (22.9 expected) in those working for a longer period.

\section{Discussion}

The overall mortality experience of this cohort of workers engaged in making chrysotile asbestos cement products since early in the second world war is low relative to levels in both the national and local populations. The same is broadly true for the main subdivisions of causes of death. There is a small degree of the so-called "healthy worker effect," but not as large as in some other occupational cohorts. 512

The $95 \%$ confidence interval for the $\mathrm{O} / \mathrm{E}$ ratio $(0.97)$ for deaths from lung cancer is from 0.69 to 1.31 , and limiting the ratio to that part of the follow up more than 20 years since first employment gives a figure of 1.01 with a $95 \%$ confidence interval of 0.65 to 1.49 . Both of these ratios are consistent with the national and local levels of lung cancer mortality, and the range of the confidence intervals would seem to rule out this cohort experiencing the high rates of some asbestos exposed workers, ${ }^{313} 14$ including those of chrysotile asbestos textile workers. ${ }^{1516}$

The one death from pleural mesothelioma occurred in 1984 in a man who had been employed by the company as a process worker from late 1977 to the middle of 1981 . His death was within seven years of the first date he could have been exposed to chrysotile asbestos at the factory, and is thus unlikely to be related to this employment. Doll and Peto have said that: "the delay from first exposure to effect ... is seldom less than 15 years, and possibly never less than 10 years." 2 This interpretation was also made at the coroner's inquest and an open verdict was returned. His main life time employment was as a kiln fireman in several brickworks for a total of over 30 years. So far as the death where asbestosis was mentioned on the death certificate is concerned, the man was employed at the factory for a total of 13 months. During this period he was recorded as working on the wet part of the process and should not have experienced particularly high exposure to asbestos fibres. It is also unlikely therefore that this case is related to employment at the factory.

There are several possible reasons why this cohort has not suffered a raised mortality from lung cancer and other asbestos related diseases. Firstly, the turnover of the workforce was high, with as many as half the employees leaving within one year of starting at the factory. The potential for long durations of exposure was thus small. Secondly, the airborne dust levels were low in comparison with other asbestos operations, due to the wet nature of the cement making process in which a large number of the cohort worked. Thirdly, the fibre type may be relevant, as workers making asbestos cement products from chrysotile only have been shown to have lower rates of lung cancer than those working with mixed fibres including amphiboles-see review in Ohlson and Hogstedt. ${ }^{17}$ Fourthly, since there are no data available on the cigarette smoking habits of the workforce, it is conceivable that they were low level smokers and that an asbestos influence was hidden. Low smoking levels, however, are unlikely among such a working population, and the nature of the lung cancer findings are also not indicative of an asbestos related effect.

A major review of published reports is not appropriate after the recent one by Ohlson and Hogstedt. ${ }^{17}$ It is of interest, however, to look at the combined results of the three studies of asbestos cement workers where chrysotile was almost exclusively the only fibre used - this study and those of Thomas et $\mathrm{al}^{5}$ and Ohlson and Hogstedt. ${ }^{17}$ Overall 76 deaths from lung cancer have been reported in men compared with 80.2 expected at national rates $(\mathrm{O} / \mathrm{E}=0.95 ; 95 \% \mathrm{CI} 0.75$ to 1.19), and of these, 52 have occurred later than 20 years since first employment (15 years in the case of Thomas et $a l^{5}$ ) compared with 52.9 expected $(\mathrm{O} / \mathrm{E}=0.98 ; 95 \% \mathrm{CI} 0.73$ to $1 \cdot 29)$. Two cases of pleural mesothelioma were found in the study by Thomas et $a l,{ }^{5}$ but these were of men who worked in the factory during its early years when crocidolite was used. No other cases of mesothelioma or asbestosis have occurred, except those mentioned in this study, nor have excesses of other asbestos related diseases been reported.

Possibly the relatively low airborne fibre levels make the asbestos cement process with chrysotile comparatively safe. The power, however, of even the three studies combined for detecting risks from other than lung cancer is limited.

We are grateful for the cooperation of TAC Construction Materials Ltd which made this study possible and for the help of their staff in many ways. We acknowledge the roles of the National Health Service Central Register in Southport and the Department of Health and Social Security in Newcastle in enabling us to follow up the workforce. We thank colleagues, past and present, for help with various aspects of the study, in particular Miss AK Adams who organised the initial data abstraction at the factory and Miss Brigid Grimes who typed the manuscript. The study was supported by a research grant from the Health and Safety Executive. 


\section{References}

1 Acheson ED, Gardner MJ. Asbestos: the control limit for asbestos. London: HMSO, 1983.

2 Doll R, Peto J. Asbestos: effects on health of exposure to asbestos. London: HMSO, 1985.

3 Selikoff IJ, Hammond EC, Seidman H. Mortality experience of insulation workers in the United States and Canada 1943-76. Ann NY Acad Sci 1979;330:61-90.

4 Berry G, Newhouse ML. Mortality of workers manufacturing friction materials using asbestos. Br J Ind Med 1983;40:1-7.

5 Thomas HF, Benjamin IT, Elwood PC, Sweetnam PM. Further follow-up study of workers from an asbestos cement factory. $\mathrm{Br}$ $J$ Ind Med 1982;39:273-6.

6 Advisory Committee on Asbestos. Asbestos: final report of the advisory committee. Vol 1. (Appendix 2.) London: HMSO, 1979.

7 Hill ID. Computing man years at risk. Br J Prev Soc Med 1972;26:132-4.

8 Gardner MJ, Winter PD, Taylor CP, Acheson ED. Atlas of cancer mortality in England and Wales 1968-78. Chichester: Wiley, 1983.

9 Gardner MJ, Winter PD, Barker DJP. Atlas of mortality from selected diseases in England and Wales 1968-78. Chichester: Wiley, 1984.

10 World Health Organisation. International Classification of Diseases. 9th rev. Geneva: WHO, 1977.

11 Gardner MJ. Considerations in the choice of expected numbers for appropriate comparisons in occupational cohort studies. Med Lav 1986;77:23-47.

12 Fox AJ, Collier PF. Low mortality rates in industrial cohort studies due to selection for work and survival in the industry. $\mathrm{Br}$ J Prev Soc Med 1976;30:225-30.

13 Newhouse ML, Berry G. Patterns of mortality in asbestos factory workers in London. Ann NY Acad Sci 1979;330:53-60.

14 Acheson ED, Gardner MJ, Winter PD, Bennett C. Cancer in a factory using amosite asbestos. Int J Epidemiol 1984;13:3-10.

15 McDonald AD, Fry JS, Woolley AJ, McDonald JC. Dust exposure and mortality in an American chrysotile textile plant. Br J Ind Med 1983;40:361-7.

16 Peto J, Doll R, Hermon C, Binns W, Clayton R, Goffe T. Relationship of mortality to measures of environmental asbestos pollution in an asbestos textile factory. Ann Occup $\mathrm{Hyg}$ 1985;29:305-55.

17 Ohlson CG, Hogstedt C. Lung cancer among asbestos cement workers: a Swedish cohort study and a review. Br J Ind Med 1985;42:397-402.

\section{Correspondence and editorials}

The British Journal of Industrial Medicine welcomes correspondence relating to any of the material appearing in the journal. Results from preliminary or small scale studies may also be published in the correspondence column if this seems appropriate. Letters should be not more than 500 words in length and contain a minimum of references. Tables and figures should be kept to an absolute minimum. Letters are accepted on the understanding that they may be subject to editorial revision and shortening.

The journal now also publishes editorials which are normally specially commissioned. The Editor welcomes suggestions regarding suitable topics; those wishing to submit an editorial, however, should do so only after discussion with the Editor. 